\title{
NICOTINE STIMULATES SECRETION OF BOTH CATECHOLAMINES AND ACETYLCHOLINESTERASE FROM CULTURED ADRENAL CHROMAFFIN CELLS ${ }^{1}$
}

\author{
FUMIO MIZOBE ${ }^{2}$ AND BRUCE G. LIVETT ${ }^{3}$ \\ Division of Neurology, The Montreal General Hospital and McGill University, Montreal, Quebec, Canada H3G 1A4
}

Received September 1, 1982; Revised November 8, 1982; Accepted November 11, 1982

\begin{abstract}
There is conflicting evidence from studies on sympathetic ganglia and the adrenal medulla concerning the morphological and biochemical localization and physiological role(s) of the enzyme acetylcholinesterase (AChE). Furthermore, the origin of the AChE released from the adrenal medulla (whether from chromaffin cells or splanchnic nerve, or both) has not been firmly established. We have examined the efficacy of cholinergic agonists to release endogenous AChE and catecholamines (CA) from monolayer cultures of purified bovine adrenal chromaffin cells. The nicotinic agonist (nicotine), but not the muscarinic agonist (methacholine), released both AChE and CA from the adrenal chromaffin cells. The concomitant release of CA and AChE evoked by nicotine was $\mathrm{Ca}^{++}$dependent with a correlation coefficient $r=0.82(p<0.001)$. The results show that adrenal chromaffin cells in vitro, a system free of splanchnic nerve elements, can still release AChE. The finding that concomitant release of $\mathrm{AChE}$ and catecholamines occurs on exposure of the cells to nicotinic agonists suggests that released AChE may have a physiological role at neuroeffector junctions.
\end{abstract}

At the neuromuscular junction, acetylcholinesterase (AChE) is localized to the postsynaptic membrane and plays an important role in the control of normal neuromuscular activity by hydrolyzing acetylcholine (ACh) following its release from nerve terminals. By contrast, the function of $\mathrm{AChE}$ in ganglionic transmission has not been firmly established (for review see Silver, 1974). Anticholinesterases do not affect ganglionic transmission as dramatically as they affect neuromuscular transmission. It has been suggested that in the ganglion the termination of transmitter action is not primarily dependent on the hydrolysis of $\mathrm{ACh}$ by $\mathrm{AChE}$ but depends more on the diffusion of $\mathrm{ACh}$ from the synapse (Emmelin and McIntosh, 1956).

Morphological observations on cholinergically innervated sympathetic ganglia (Somogyi and Chubb, 1976;

\footnotetext{
' We thank Mr. L. Whelan for technical assistance and Mrs. G. Peard and Mrs. A. Derzsy for typing the manuscript. This work was supported by a grant to B. G. L. from the Medical Research Council of Canada (PG 20). We thank the Muscular Dystrophy Association of Canada for a postdoctoral fellowship to F. M.

${ }^{2}$ Present address: Tokyo Metropolitan Institute of Gerontology, 352 Sakaecho, Itabashiku, Tokyo-173, Japan.

${ }^{3}$ To whom correspondence should be addressed at his present address: Department of Biochemistry, University of Melhourne, Parkville, 3052 , Victoria, Australia.
}

Gisiger et al., 1978) and the adrenal medulla (Somogyi et al., 1975) show that relatively little AChE is associated with the plasma membrane adjacent to the presynaptic cholinergic terminals. Rather, AChE has been demonstrated by ultrastructural histochemistry to be sequestered in cisternae of the endoplasmic reticulum of the target cells. The function of the cisternal AChE is not known. Recent evidence suggests that spontaneous release of $\mathrm{AChE}$ occurs from neuronal cells in vivo (Kreutzberg and Toth, 1974) and in vitro (SkangielKramska and Niemierko, 1975) and from cultured muscle (Wilson et al., 1973), spinal cord (Oh et al., 1977), sympathetic ganglia (Gisiger and Vigny, 1977), and neuroblastoma (Oh et al., 1977; Kimhi et al., 1980; Lazar and Vigny, 1980) cells. Enhanced AChE release has also been demonstrated from unidentificd central neurons into cerebrospinal fluid following electrical and pharmacological (Chubb et al., 1976; Bareggi and Giacobini, 1978; Greenfield et al., 1979; Greenfield and Smith, 1979) stimulation, into the perfusates collected from cannulated cat substantia nigra and caudate nucleus (Greenfield et al., 1980) and retrogradely perfused bovine adrenal glands (Chubb and Smith, 1975), and into the incubation medium obtained from stimulated rat phrenic nerve-hemidiaphragm preparations (Skau and Brimijoin, 1978).

In an earlier study (Mizobe and Livett, 1980) we provided evidence for the production and spontaneous 
release of $\mathrm{AChE}$ from primary monolayer cultures of bovine adrenal chromaffin cells. Monolayer cultures of adult bovine chromaffin cells can be isolated and maintained under conditions free of non-neuronal cells and splanchnic nerve influence (Livett et al., 1978). These cultured cells are readily accessible to reagents added to the incubation medium which can be easily and rapidly changed. Moreover, release is not complicated by diffusion barriers present in intact tissue. Therefore, primary cultures of bovine adrenal chromaffin cells provide a useful experimental system for investigating the evoked release of $\mathrm{AChE}$.

We now show that in adrenal chromaftin cells, an in vitro system free of splanchnic nerve elements, concomitant release of $\mathrm{AChE}$ and catecholamines occurs following nicotinic stimulation. The origin of the released AChF is not certain. It could conceivably come from exocytosis of chromaffin vesicles, or from the cisternae. In view of the histochemical evidence that most of the $\mathrm{AChE}$ is located in cisternae, we suggest that the release of AChE is parallel but separate from the release of catecholamines, the release of AChE most likely occurring from the cisternae into the extracellular space.

\section{Materials and Methods}

\section{Cell culture and pharmacological stimulation}

Primary cultures of adrenal chromaffin cells were established as monolayers on collagen-coated plastic dishes and maintained in Dulbecco's modified Eagle's medium (DMEM, Gibco) - 10\% fetal calf serum, heat inactivated (FCS) (Livett et al., 1978) containing 5-fluorodeoxyuridine $\left(10^{-5} \mathrm{M}\right)$ and cytosine arabinoside $\left(10^{-5} \mathrm{M}\right)$, to prevent the proliferation of non-neuronal cells (see Livett et al., 1979; Mizobe et al., 1979). After 7 to 11 days in culture, the cells were washed thoroughly with DMEM and a HEPES-buffered Krebs-Ringer saline (KRH) (Mizobe et al., 1979). Afterward, the cells were incubated in KRH medium with or without (control) a secretagogue for $8 \mathrm{~min}$ at $37^{\circ} \mathrm{C}$ to study the release of endogenous catecholamines and AChE. Nicotine and methacholine were used as secretagogues.

Assay of catecholamines. Endogenous catecholamines (both within the cells and released into the media) were assayed by the two-wavelength differential spectrofluorimetric procedures of Renzini et al. (1970) and Miura et al. (1977) as described elsewhere (Livett et al., 1981).

Assay of AChE. AChE activity was measured by the radiometric method of Johnson and Russell (1975) with minor modification. The assay mixture contained $80 \mu \mathrm{l}$ of the supernatant of incubation media or cell homogenates in KRH medium (pH 7.2) and $20 \mu \mathrm{l}$ of acetylcholine substrate $\left(\left[{ }^{3} \mathrm{H}\right]\right.$ acetylcholine chloride, specific activity 3.9 $\mathrm{Ci} / \mathrm{mol}$, final $\left.5.1 \times 10^{-4} \mathrm{M}\right)$. Reactions were started by addition of the substrate, and incubations were carried out at $37^{\circ} \mathrm{C}$ for period of 10 to $20 \mathrm{~min}$. The reaction was stopped by adding $0.1 \mathrm{ml}$ of stopping mixture $(1 \mathrm{M}$ chloroacetic acid, $0.5 \mathrm{M} \mathrm{NaOH}$, and $2 \mathrm{~m} \mathrm{NaCl}, \mathrm{pH} 2.5$ ), followed by adding $4.5 \mathrm{ml}$ of scintillation mixture $(100 \mathrm{ml}$ of isoamyl alcohol, $4 \mathrm{gm}$ of 2,5-diphenyloxazole (PPO), $50 \mathrm{mg}$ of 1,4-bis-2-(5-phenyloxazolyl)-benzene (POPOP) in 1 liter of toluene). Appropriate blanks were included in which $\mathrm{KRH}$ medium was added instead of the enzyme samples. Radioactivity was measured in a scintillation counter with a counting efficiency of $49 \%$. The enzyme reaction was linear with time for more than $25 \mathrm{~min}$, was proportional to enzyme concentration, and was inhibited completely by $4 \times 10^{-5} \mathrm{M}$ eserine. 'Total cholinesterase activity, both within the cells and released into the incubation medium, was inhibited 92 to $96 \%$ by the specific AChE inhibitor, 1,5-bis-(4-allyldimethylammonium-phenyl)pentan-3-one dibromide (BW 284C51, $5 \times$ $10^{-6} \mathrm{M}$ ), indicating that essentially all the activity was present as true acetylcholinesterase (Klingman et al., 1968; Silver, 1974).

\section{Results}

Release of catecholamines and AChE. Figure 1 shows the time course of the release of endogenous catecholamine and cellular AChE from bovine adrenal chromaffin cells stimulated with nicotine $\left(10^{-5} \mathrm{M}\right)$. The release of endogenous catecholamines evoked by nicotine was quite rapid and 90 to $100 \%$ of maximum release occurred within 5 min, consistent with our earlier observations on the time course of release of $\left[{ }^{3} \mathrm{H}\right]$ noradrenaline evoked by ACh (Mizobe et al., 1979). Nicotinic stimulation produced a similar rapid release of $\mathrm{AChE}$ which occurred in parallel with the release of catecholamines (Fig. 1).

Characterization of nicotinic response. The nicotinic receptor response of many cell types shows a characteristic activation at low levels of agonist $\left(10^{-7}\right.$ to $10^{-5} \mathrm{M}$ nicotine) and an inhibition ("desensitization") (Katz and Thesleff, 1952) at higher levels $\left(>10^{-4} \mathrm{M}\right)$. In accord with this general property, the nicotine-evoked release of endogenous catecholamines and AChE in the presence of $\mathrm{Ca}^{2+}$ (Fig. 2) showed similar dose response curves with inhibition at high concentrations of agonist. The release of both catecholamines and AChE evoked by nicotine was dependent on extracellular $\mathrm{Ca}^{++}$as shown in Figure 2 . When the cells were exposed to nicotine in the absence of extracellular $\mathrm{Ca}^{++}$, the release of AChE and catecholamines (Mizobe et al., 1979) was at or below the basal level. Nicotine-induced release of cellular AChE was highly significant at $5 \times 10^{-6} \mathrm{M}$ and $10^{-5} \mathrm{M}$ (the Student's $t$ test, $p<0.001$ ), even though the maximum release (at $10^{-5} \mathrm{M}$ ) was only $1 \%$ higher than basal release. In contrast, the muscarinic agonist, methacholine $\left(10^{-6}\right.$ to $\left.10^{-3} \mathrm{M}\right)$ did not stimulate the release of endogenous catecholamines and AChE (data not shown). Nicotine $\left(10^{-5}\right.$ M) and methacholine $\left(10^{-4} \mathrm{M}\right)$ by themselves did not have any effect on the enzyme assay for AChE activity.

Proportionality of AChE and catecholamine released. The net evoked release of the AChE was proportional to that of catecholamines over the range of nicotine concentrations used $\left(5 \times{ }^{-7}\right.$ to $\left.10^{-5} \mathrm{M}\right)$ (Fig. 3). The correlation coefficient $(r=0.819)$ between released $\mathrm{AChE}$ and catecholamines was significant at the $p<0.001$ level.

\section{Discussion}

Our results show that nicotinic stimulation of chromaffin cells in vitro brings about the simultaneous release of AChE and endogenous catecholamines. The release evoked by $\mathrm{ACh}$ and nicotine was $\mathrm{Ca}^{++}$-dependent, suggestive of exocytosis. There is good evidence that 


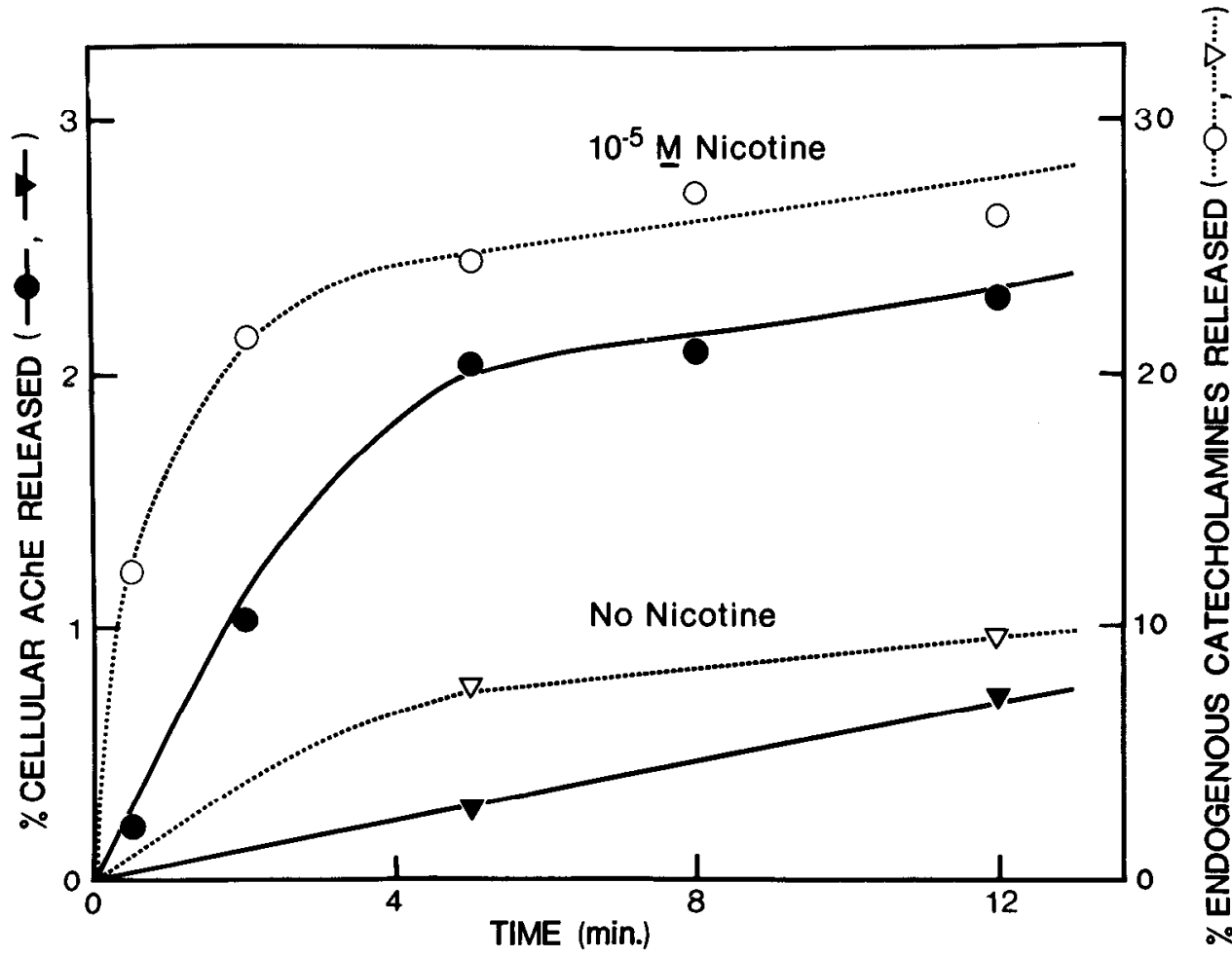

Figure 1. Time course of release of endogenous catecholamines and AChE in the presence and absence of nicotine. Chromaffin cells $\left(2.5 \times 10^{5}\right.$ cells/well) were maintained in $16 \mathrm{~mm}, 24$-well plastic cluster dishes (Falcon) containing $0.5 \mathrm{ml}$ of DMEM-10\% FCS. At day 8, cultures were washed with DMEM (serum free) and incubated in DMEM for $1 \mathrm{hr}$ at $37^{\circ} \mathrm{C}$. The cultures were then washed twice by incubation in $\mathrm{KRH}$ medium at $37^{\circ} \mathrm{C}$ for $15 \mathrm{~min}$. After pre-incubation in $0.3 \mathrm{ml}$ of $\mathrm{KRH}$ medium for an additional $8 \mathrm{~min}$, the cultures were incubated in $0.3 \mathrm{ml}$ of $\mathrm{KRH}$ medium with $\left(O\right.$,, ) or without $(\nabla, \nabla) 10^{-5} \mathrm{M}$ nicotine to evoke release. At the time indicated, the incubation media were removed from the cells, placed on ice, and centrifuged at $30,000 \times g$ for $30 \mathrm{~min}$. The supernatant was recovered to measure catecholamines $(O, \nabla)$ and AChE activity $(\mathbf{Q}, \nabla)$. The cells were scraped off the plate and homogenized in $1.5 \mathrm{ml}$ of KRH medium, and aliquots were used for assay of catecholamines and AChE activity (see "Materials and Methods"). The 8-day-old cultures contained $212 \pm 5$ (mean \pm SEM, $n=14$ ) nmol of catecholamines per $10^{6}$ cells, and an AChE activity of $3.74 \pm 0.11(n=14) \mathrm{nmol}$ of $\mathrm{ACh}$ hydrolyzed $\mathrm{min}^{-1}$ per $10^{6}$ cells. The release of endogenous catecholamines and $\mathrm{AChE}$ from the cells into the medium is expressed as a percentage of the total content in the cells. 'The results of a typical preparation are shown where each point represents the average of duplicate determinations.

release of catecholamines from the cells occurs by exocytosis of the chromaffin granules (Douglas, 1968; Fenwick et al., 1978); however, there is no convincing evidence that $\Lambda \mathrm{ChE}$ is secreted by this mechanism. Biochemical studies have given conflicting information about the distribution of AChE in chromaffin cells. Whereas Wilson and Kirshner (1977) found no evidence for AChE being localized to chromaffin vesicles, Gratzl et al. (1981) reported both membrane-bound and soluble (latent) forms of the enzyme associated with purified chromaffin vesicles. Cytochemical studies on glutaraldehyde-fixed tissue by Somogyi et al. (1975) on the cow, and more recently by Millar and Unsicker (1981) on the rat, and by Carmichael (1982) on cow, pig, and hamster adrenals have localized AChE activity on the external plasma membrane, within the smooth endoplasmic reticulum, and on the nuclear envelope of chromaffin cells but not on or within the chromaffin vesicles. However, when Vibratome sections of fresh adrenal medullae were incubated with the enzyme substrates for up to $60 \mathrm{~min}$ prior to fixation, Carmichael (1982) demonstrated that low but detectable levels of AChE activity were associated with chromaffin vesicles. The cytochemical results, when taken together with the biochemical data of Gratzl et al. (1981), suggest that $\mathrm{AChE}$ is normally associated with the membrane and soluble contents of chromaffin vesicles where it is present either in low amounts or in a latent form. Since in the present experiments, only a few percent of the total $\mathrm{AChE}$ content was released by nicotinic stimulation, a minority source such as the chromaffin vesicles cannot be excluded.

In the intact animal, activation of ACh receptors on adrenal chromaffin cells is brought about by release of ACh from splanchnic nerve terminals innervating the medulla, resulting in the release of catecholamines into the circulation. In a similar manner, our earlier studies on bovine adrenal chromaffin cells showed that $\left[{ }^{3} \mathrm{H}\right]$ noradrenaline $\left(\left[{ }^{3} \mathrm{H}\right] \mathrm{NA}\right)$ taken up and stored in reserpinesensitive sites was released from the cells by activation of nicotinic (but not muscarinic) ACh receptors (Mizobe et al., 1979). Earlier studies by Chubb and Smith (1975) on perfused bovine adrenal glands suggest that, after stimulation with nicotinic agonists and high $\mathrm{K}^{+}, \mathrm{AChE}$ is released into perfusates from the glands, i.e., primarily from the chromaffin cells and possibly from the splanchnic nerves as well. Our present observations with the 


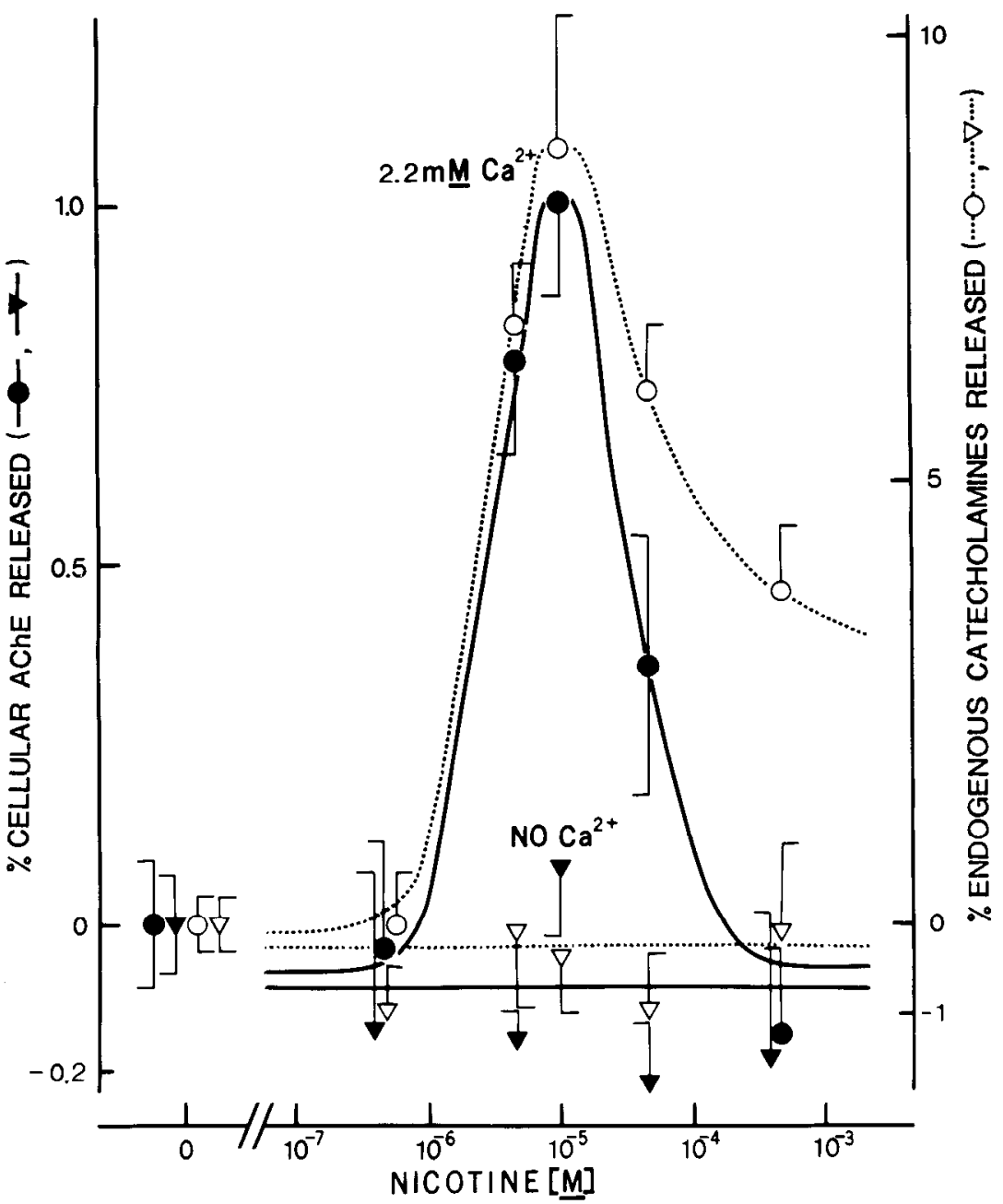

Figure 2. Dose response curves for release of endogenous catecholamines and AChE by nicotine in the presence and absence of $\mathrm{Ca}^{2+}$. At day 7 to 11, adrenal chromaffin cells were processed for release experiments as described in the legend to Figure 1 . The cells were pre-incubated for $8 \mathrm{~min}$ in $\mathrm{KRH}$ medium with no $\mathrm{Ca}^{++}$added, or containing $2.2 \mathrm{~mm} \mathrm{Ca}{ }^{2+}$, and then incubated for 8 min with various concentrations of nicotine in the absence $(\nabla, \nabla)$ or presence $(O, \bigcirc)$ of $\mathbf{C a}^{++}$at $37^{\circ} \mathrm{C}$. Endogenous catecholamines $(O, \nabla)$ and AChE $(\mathbf{O}, \mathbf{\nabla})$ (both within the cells and released into the media) were assayed as described under "Materials and Methods." These cultures from six preparations contained $315 \pm 64 \mathrm{nmol}$ of catecholamines per $10^{6}$ cells and AChE activity of $4.97 \pm 1.14 \mathrm{nmol} \mathrm{min}{ }^{-1}$ per $10^{6}$ cells. Basal release, which was obtained from duplicate wells, has been subtracted from the release data. The basal release (i.e., the release in the absence of nicotine) from the cells plated on multiwells amounted to $8.8 \pm 1.0 \%$ $(n=12)$ of endogenous catecholamines in the presence of $\mathrm{Ca}^{2+}(2.2 \mathrm{mM})$ and $9.3 \pm 1.7 \%(n=6)$ in the absence of $\mathrm{Ca}^{2+} ; 1.37 \pm$ $0.25 \%(n=12)$ of AChE in the presence of $\mathrm{Ca}^{2+}$ and $1.57 \pm 0.30 \%(n=6)$ in the absence of $\mathrm{Ca}^{2+}$. The results are given as mean $\pm \operatorname{SEM}(n=4$ to 12$)$.

isolated chromaffin cells in culture which are free from any splanchnic nerve influence show that upon depolarization AChE activity is released from the chromaffin cells themselves. Since most of the AChE activity in the adrenal medulla has been localized to cisternae of endoplasmic reticulum, with some on the plasma membrane, it is most likely that the released AChE originates from these cisternae (see Chubb, 1977). However, the possibility is not excluded that some, or all, of the released $\mathrm{AChE}$ activity might originate from the plasma membrane or from chromaffin vesicles (Gratzl et al., 1981; Carmichael, 1982). Whatever the source of the released AChE, the mechanism of this release seems to share features of stimulus-secretion coupling (Douglas, 1968) responsible for the release of catecholamines from chromaffin cells.

Our earlier studies (Mizobe and Livett, 1980, 1982) showed that a specific anti-acetylcholinesterase, BW-
284C51, which does not readily penetrate the plasma membrane of cells (McIsaac and Koelle, 1959; Silver, 1974) restored the efficacy of ACh to stimulate the bovine adrenal chromaffin cells, indicating that AChE located on the external surface of the plasma membrane may hydrolyze exogenously applied ACh. The present results showing that nicotine stimulates the release of $\mathrm{AChE}$ from the chromaffin cells suggests that exogenously applied ACh may be hydrolyzed not only by AChE located on the plasma membranes, but also by soluble AChE secreted from the cells in response to the agonist.

The function of the released $\mathrm{AChE}$ is not known (Chubb, 1977). In the adrenal medulla the secreted AChE might function to remove excess ACh from any further pharmacological effects, particularly in those regions where membrane-bound AChE is sparse or not present (Somogyi et al., 1975), and to provide choline for re- 


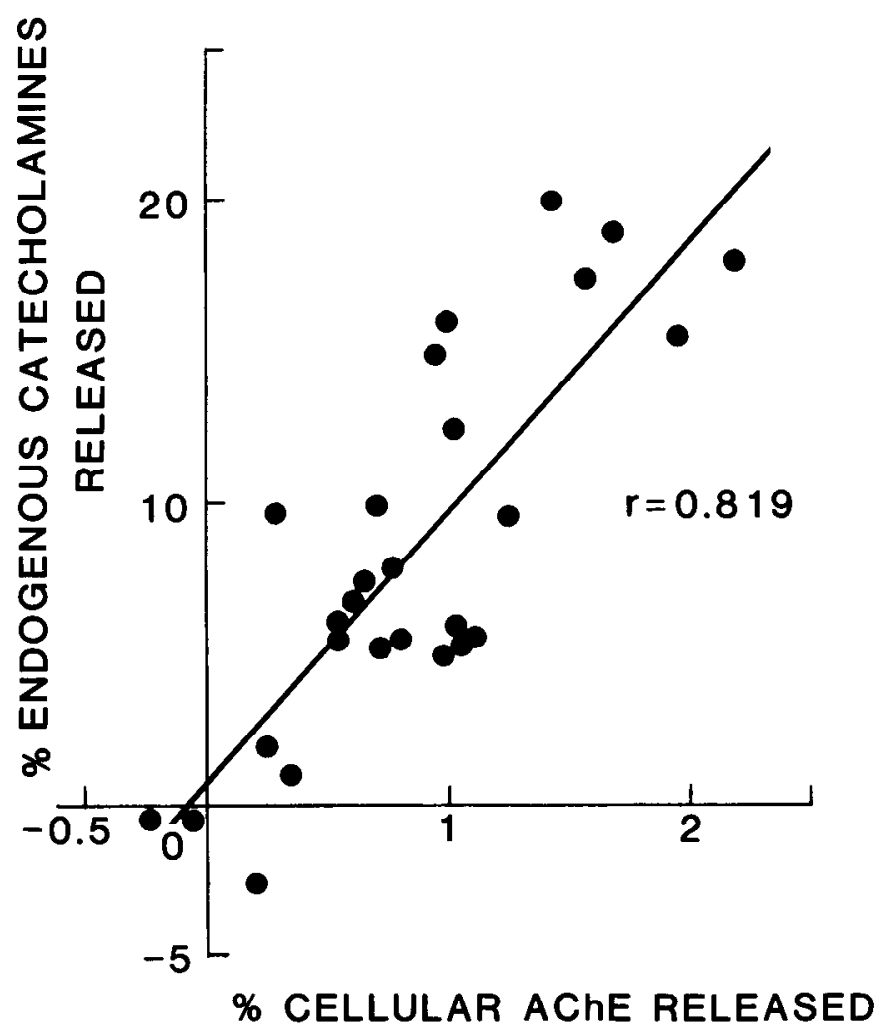

Figure 3. Correlation between AChE released and endogenous catecholamine released from bovine adrenal chromaffin cells by nicotine. Data are expressed as percentage of the total cellular content of $\mathrm{AChE}$ or endogenous catecholamines released by nicotine over the range $5 \times 10^{-7} \mathrm{M}$ to $10^{-5} \mathrm{M}$. Basal release has been subtracted from the release data (see legends to Figs. 1 and 2 for details). The solid line is drawn according to the equation $y=8.87 x+0.78$, as determined by linear regression analysis (correlation coefficient $r=0.819, p<0.001$, $n=27)$.

uptake or resynthesis of $\mathrm{ACh}$ in splanchnic nerve terminals as proposed for sympathelic ganglia (Gisiger and Vigny, 1977). Recently, it has been reported that highly purified AChE from both fetal calf serum and electric eel has peptidase activity and can hydrolyze both substance P (Chubb et al., 1980) and Leu- and Met-enkephalin (Chubb et al., 1982). AChE seems to show some selectivity in its action because it does not hydrolyze two other neuropeptides (somatostatin and neurotensin) endogenous to the adrenal medulla or a number of other neuropeptides, including $\beta$-endorphin, oxytocin, vasopressin, and angiotensin II (Chubb et al., 1982). Inasmuch as substance $P$ and the enkephalins are endogenous components of the splanchnic nerve that innervates the adrenal medulla (Schultzberg et al., 1978; Linnoila et al., 1980) and act as inhibitory modulators of the nicotinic response of chromaffin cells to release catecholamines (Livett et al., 1979; Mizobe et al., 1979; Role et al., 1981), it suggests that another function of the released AChE might be to hydrolyze these peptides, so terminating their biological activity. Whatever the precise function(s) of the released $\mathrm{AChE}$, the present demonstration that $\mathrm{AChE}$ and catecholamines are released concomitantly upon nicotinic stimulation provides a mechanism by which the chromaffin cell could ensure prompt termination of the effects of splanchnic nerve stimulation.

\section{References}

Bareggi, S. R., and E. Giacobini (1978) Acetylcholinesterase activity in ventricular and cisternal CSF of dogs: Effect of chlorpromazine. J. Neurosci. Res. 3: 335-339.

Carmichael, S. W. (1982) Cytochemistry of the adrenal chromaffin cell: Localization of adenylate cyclase and acetylcholinesterase. Soc. Neursci. Abstr: 8: 409.

Chubb, I. W. (1977) The release of non-transmitter substances. In Synapses G. A. Cottrell and P. N. R. Usherwood, eds., pp. 264-290, Blackie, Glasgow and London.

Chubb, I. W., and A. D. Smith (1975) Release of acetylcholinesterase into the perfusate from the ox adrenal gland. Proc. R. Soc. Lond. Biol. 191: 263-269.

Chubb, I. W., S. Goodman, and A. D. Smith (1976) Is acetylcholinesterase secreted from central neurons into the cerebrospinal fluid? Neuroscience 1: 57-62.

Chubb, I. W., A. J. Hodgson, and G. H. White (1980) Acetylcholinesterase hydrolyzes substance P. Neuroscience 5: 20652072.

Chubh, I. W., F. Ranieri, A. I. Hodgson, and G. H. White (1982) The hydrolysis of Leu- and Met-enkephalin by acetylcholinesterase. Neurosci. Lett. (Suppl.) 8: S39.

Douglas, W. W. (1968) Stimulus-secretion coupling: The concept and clues from chromaffin and other cells. Br. J. Pharmacol. 34: 451-474.

Emmelin, N., and F. C. McIntosh (1956) The release of acetylcholine from perfused sympathetic ganglia and skeletal muscles. J. Physiol. (Lond.) 131: 477-496.

Fenwick, E. M., P. B. Fajdiga, N. B. S. Howe, and B. G. Livett (1978) Functional and morphological characterization of isolated bovine adrenal medullary cells. J. Cell Biol. 76: 12-30.

Gisiger, V., and M. Vigny (1977) A specific form of acetylcholinesterase is secreted by rat sympathetic ganglia. FEBS Lett. 84: $253-256$.

Gisiger, V., M. Vigny, J. Gautron, and F. Rieger (1978) Acetylcholinesterase of rat sympathetic ganglion: Molecular forms, localization and effects of denervation. J. Neurochem. 30: 501-516.

Gratzl, M., H. Krieger-Brauer, and R. Ekerdt (1981) Latent acetylcholinesterase in secretory vesicles from adrenal medulla. Biochim. Biophys. Acta 649: 355-366.

Greenfield, S., A. Cheramy, V. Leviel, and J. Glowinski (1980) In vivo release of acetylcholinesterase in cat substantia nigra and caudate nucleus. Nature 284: 355-357.

Greenfield, S. A., and A. D. Smith (1979) The influence of electrical stimulation of certain brain regions on the concentration of acetylcholinesterase in rabbit cerebrospinal fluid. Brain Res. 177: 445-459.

Greenfield, S. A., I. W. Chubb, and A. D. Smith (1979) The effect of chlorpromazine on the concentration of acetylcholinesterase in the cerebrospinal fluid of rabbits. Neuropharmacology 18: 127-132.

Johnson, C. D., and R. L. Russell (1975) A rapid, simple radiometric assay for cholinesterase, suitable for multiple determinations. Anal. Biochem. 64: 229-238.

Katz, B., and S. Thesleff (1952) A study of the "desensitization" produced by acetylcholine at the motor end-plate. J. Physiol. (Lond.) 138: 63-80.

Kihmi, Y., A. Mahler, and D. Saya (1980) Acetylcholinesterase in mouse neuroblastoma cells: Intracellular and released enzyme. J. Neurochem. 34: 554-559.

Klingman, G. I., J. D. Klingman, and A. Poliszczuk (1968) Acetyl- and pseudocholinesterase activities in sympathetic ganglia of rats. J. Neurochem. 15: 1121-1130.

Kreutzberg, G. W., and L. Toth (1974) Dendritic secretion: A 
way for the neuron to communicate with the vasculature. Naturwissenschaften $61: 37$.

Lazar, M., and M. Vigny (1980) Modulation of the distribution of acetylcholinesterase molecular forms in a murine neuroblastoma X sympathetic ganglion cell hybrid cell line. J. Neurochem. 35: 1067-1079.

Linnoila, R. I., R. P. Diaugustine, A. Hervonen, and R. J. Miller (1980) Distribution of $\mathrm{Met}^{5}$ - and Leu ${ }^{5}$-enkephalin, vasoactive intestinal polypeptide and substance P-like immunoreactivities in human adrenal glands. Neuroscience 5: 2247-2259.

Livett, B. G., D. M. Dean, and G. M. Bray (1978) Growth characteristics of isolated adrenal medullary cells in culture. Soc. Neurosci. Abstr. 4: 592.

Livett, B. G., V. Kozousek, F. Mizobe, and D. M. Dean (1979) Substance $\mathrm{P}$ inhibits nicotinic activation of chromaffin cells. Nature 278: 256-257.

Livett, B. G., D. M. Dean, L. G. Whelan, S. Udenfriend, and J. Rossier (1981) Co-release of enkephalin and catecholamines from cultured adrenal chromaffin cells. Nature 289: 317-319.

McIsaac, R. J., and G. B. Koelle (1959) Comparison of the effects of inhibition of external, internal and total acetylcholinesterase upon ganglionic transmission. J. Pharmacol. Exp. Ther. 126: 9-20.

Millar, T. J., and K. Unsicker (1981) Catecholamine-storing cells in the adrenal medulla of the pre- and postnatal rat: Acetylcholinesterase as a means for early discrimination of cell types. Cell Tissue Res. 217: 155-170.

Miura, Y., V. Campese, V. DeQuattro, and D. Meijer (1977) Plasma catecholamines via an improved fluorimetric assay: Comparison with an enzymatic method. J. Lab. Clin. Med. 89: 421-427.

Mizobe, F., and B. G. Livett (1980) Production and release of acetylcholinesterase by a primary cell culture of bovine adrenal medullary chromaffin cells. J. Neurochem. 35: 14691472 .

Mizobe, F., and B. G. Livett (1982) Biphasic effect of eserine and other acetylcholinesterase inhibitors on the nicotinic response to acetylcholine in cultured adrenal chromaffin cells. J. Neurochem. 39: 379-385.

Mizobe, F., V. Kozousek, D. M. Dean, and B. G. Livett (1979)
Pharmacological characterization of adrenal paraneurons: Substance $P$ and somatostatin as inhibitory modulators of the nicotinic response. Brain Res. 178: 555-566.

Oh, T. H., J. Y. Chyu, and S. R. Max (1977) Release of acetylcholinesterase by cultured spinal cord cells. J. Neurobiol. 8: 469-476.

Renzini, V., C. A. Brunori, and C. Valori (1970) A selective and specific fluorimetric method for the determination of noradrenalin and adrenalin in human plasma. Clin. Chim. Acta 30: $587-594$.

Role, L. W., R. L. Perlman, and S. E. Leeman (1981) Somatostatin and substance $\mathrm{P}$ inhibit catecholamine secretion from isolated cells of guinea pig adrenal medulla. Neuroscience 6 : 1813-1821.

Schultzberg, M., J. M. Lundberg, T. Hökfelt, L. Terenius, J. Brandt, R. P. Elde, and M. Goldstein (1978) Enkephalin-like immunoreactivity in gland cells and nerve terminals of the adrenal medulla. Neuroscience 3: 1169-1186.

Silver, A. (1974) The Biology of Cholinesterases, North-Holland, Amsterdam.

Skangiel-Kramska, J., and S. Niemierko (1975) Soluble and particle-bound acetylcholinesterase and its isoenzymes in peripheral nerve. J. Neurochem. 24: 1135-1141.

Skau, K. A., and S. Brimijoin (1978) Release of acetylcholinesterase from rat hemidiaphragm preparations stimulated through the phrenic nerve. Nature 275: 224-226.

Somogyi, P., and I. W. Chubb (1976) The recovery of acetylcholinesterase activity in the superior cervical ganglion of the rat following its inhibition by diisopropylphosphorofluoridate: A biochemical and cytochemical study. Neuroscience 1: 413-421.

Somogyi, P., I. W. Chubb, and A. D. Smith (1975) A possible structural basis for the extracellular release of acetylcholinesterase. Proc. R. Soc. Lond. Biol. 191: 271-283.

Wilson, S. P., and N. Kirshner (1977) The acetylcholine receptor of the adrenal medulla. J. Neurochem. 28: 687-695.

Wilson, B. W., P. S. Nieberg, C. R. Walker, T. A. Linkhart, and D. M. Fry (1973) Production and release of acetylcholinesterase by cultures chick embryo muscle. Dev. Biol. 33: 285299. 